\title{
Strategies used in Mobilizing Physical Resource in Kilolo District Public Secondary Schools, Tanzania
}

\author{
Hyacinta Raymond Mgaya \\ Orcid: https://orcid.org/0000-0002-8583-8237 \\ Department of Education Foundations, St. Augustine University of Tanzania \\ Email: hyacintamgaya@gmail.com \\ Daniel Oduor Onyango, PhD \\ Orcid: https://orcid.org/0000-0002-5381-226X \\ Department of Education Foundations, St. Augustine University of Tanzania \\ Email: jumadan06@gmail.com
}

Corresponding Mail: jumadan06@gmail.com

\begin{abstract}
Copyright resides with the author(s) in terms of the Creative Commons Attribution CC BY-NC 4.0. The users may copy, distribute, transmit and adapt the work, but must recognize the author(s) and the East African Journal of Education and Social Sciences
\end{abstract}

\begin{abstract}
This study sought to establish strategies used in mobilizing physical resource through the mixed research approach under which convergent parallel design was used. The study was conducted across 26 public secondary schools in Kilolo District with 662 teachers, 26 heads of schools and one District Education Officer (DEO). Five heads of schools and the DEO were purposively selected to take part in the interview while 81 teachers were randomly selected to take part in the study through the questionnaire. Quantitative data was analysed using descriptive statistics with the help of the SPSS while qualitative data was analysed thematically. The study established that the most used strategy in mobilizing resources was funds from income generation activities followed by involvement of the community in construction of school buildings, purchase of desks and repair of broken furniture. Since physical resources are one of most important tools for curriculum implementation, the study recommends that the use of different strategies to mobilize physical resources should be considered by schools under investigation.
\end{abstract}

Keywords: Physical resources; mobilization; strategies, public secondary schools; curriculum

How to cite: Mgaya, H. R., and Onyango, D. O. (2022). Strategies used in Mobilizing Physical Resource in Kilolo District Public Secondary Schools, Tanzania. East African Journal of Education and Social Sciences 3(1), 83-88. Doi: https://doi.org/10.46606/eajess2022v03i01.0149.

\section{Introduction}

The aim of this study was to investigate the strategies used to mobilize physical resources among public secondary schools in Kilolo District. This is because resources are the most important tools in education systems as no educational goal can be achieved without having sufficient resources. Oladeji (2019) sees physical resources as the school plant which includes school buildings, classrooms, libraries, laboratories, toilet facilities, offices and other materials and infrastructures that would likely motivate students towards learning and teachers to effectively teach.

Nzikako and Warue (2018) suggest that seeking resources from external donor funding, local fundraising and community participation can be employed as resource mobilization strategies. Basing on this view point, mobilization is the core source of sustainable resources in secondary schools. Through local fundraising, schools can be able to raise funds for physical resources and for curriculum implementations. Resource mobilization is therefore a key instrument for organizational 
sustainability and is the core part for lifespan of an organization.

Batti (2014) observes resource mobilization as the component of great value in making an organization stronger. The author further argues that mobilization strategies in learning institutions assure sustainable availability of essential resources in order to inspire teachers to teach and students to learn effectively. Abdulkareem and Fasasi (2014) maintain that to fulfil educational objectives, essential resources should be central to the extent that school members enjoy their stay and have a sense of belonging, which in turn stimulate performance.

A study by Dahie, Mohamed and Mohamed (2017) shows that the government of New York has put in place a program to make sure that all public secondary schools have the necessary physical facilities, instructional materials, and other essential resources which are important for a sound teaching and learning practices. Likewise, Mutindi (2018) reveals that in developed countries like United Kingdom, United States of America, Germany and France, the governments mobilize physical resources for the education sectors. This is due to the fact that physical and other educational resources play a vital role in ensuring that the curriculum is effectively implemented in all levels of education. The outcome of these initiatives is quality education. Resource mobilization requires the applications of various strategies for the purpose of attaining the stated educational goals. This is due to the fact that physical and other educational resources play a vital role in ensuring that curriculum is effectively implemented in all levels of education.

A study by Muhangi (2019) on secondary education in Uganda: resource mobilization and efficiency shows that resources have been not mobilized to allow secondary schools in the country to fully realize governments' existing plans for secondary education. This implies that proper strategies need to be put in place to mobilize the available physical resources in order to avoid challenges that interfere with curriculum implementation in secondary education.

While shortage of physical resources is among challenges facing the process of teaching and learning in secondary schools, Lyimo, Too and Kipng'etich (2017) present the fact that there is deficiency of physical resources like classrooms, desks and chairs in most public secondary schools in Tanzania. Classrooms are poorly constructed with scarce spacing. This situation hampers the effective implementation of secondary education curriculum since it is difficult to conduct teaching and learning more efficiently in a school which encounters shortage of physical resources. This might be occurring because during the students' enrolment expansion, the government invested little in expansion of schools infrastructures. In response to this problem, this study sought to determine the strategies used in mobilizing physical resources among public secondary schools in Kilolo district.

\section{Literature Review}

This section presents the review of literature and studies about strategies used in mobilizing physical resources in secondary Schools.

\section{Mobilization of Funds}

One of potential strategies for attainment of required physical resources in secondary schools is mobilization of funds. In school setup, fundraising can be done by organizing special events such as parent days.

In Nigeria, a study by Eric and Roseline (2019) on physical resources availability and academic performance in the Universal Basic Education Scheme revealed that availability of physical resources is critical for curriculum to be well implemented because both students and teachers need such resources so as to be able to play their teaching and learning roles effectively. Consequently, schools as education institutions should use mobilized funds to acquire physical facilities such as quality classrooms and others facilities.

As part of mobilization, Cheryan, Ziegler, Plant and Meltozoff (2014) suggest that governments should use funds to restructure appropriate physical resources like classrooms and to provide schools with sufficient space for effective teaching and learning. In response to this, in the year 2015, under the leadership of the late President John Pombe Joseph Magufuli, the government of Tanzania abolished tuition fees for secondary education and provided required resources for teaching and learning.

Makore and Shukuru (2017) suggested that informing higher authorities on scarcity of required resource can be one of appropriate strategies in resource mobilization. To cover the shortage of 
classrooms during the Covid Pandemic, the President of Tanzania, Samia Suluhu Hassan mobilized funds which are being used to construct classrooms in public schools. Therefore, school leaders should be in touch with government authorities to ensure that the government does what is required to support the schools. They also suggested that schools should use their funds to buy required resources in order to reduce the magnitude of challenges. Furthermore, parents can contribute to curb the deficit. These suggest that attainment of required resources needs a combined effort of various school stakeholders.

\section{Project Write-ups}

According to Castillo (2014) schools should learn how to create good relationships with a variety of donors who can feel the challenge that schools face and provide them with the required support through various ways including project write-ups.

\section{Community Involvement}

There is a need for schools to involve the community in mobilizing required resources that are essential for the running of schools in order to achieve intended goals. Siperato (2018) recommended that governments in collaboration with local communities should build more schools and mobilize other physical resources. Resource mobilization is a joint effort and not the work of one person or the school alone. On the contrary, African countries miss the required link between various stakeholders in fund mobilization. In Nigeria, for instance, there is poor community participation in the development of schools because schools depended on the government to finance them and community members believed that it is the role of the government to mobilize all physical resources (Kanau and Haruna, 2013). It is from this perspective that this study sought to establish strategies used in mobilizing physical resources among public secondary schools in Kilolo District.

\section{Methodology}

This section presents the research design, population and sampling techniques, instruments and data collection procedures, statistical treatment of data and ethical considerations.

\section{Research Design}

The study adopted the mixed research approach under which convergent parallel design was used.

\section{Population and Sampling Techniques}

The study was conducted across 26 public secondary schools in Kilolo District with 662 teachers, 26 heads of schools and one District Education Officer (DEO). Five heads of schools and the DEO were purposively selected to take part in the interview because the researchers believed they had crucial information about the study. On the other hand, 81 teachers were randomly selected to take part in the study through the questionnaire.

\section{Instrumentation}

Questionnaires, an interview guide and observation checklist were used for data collection. A pilot study was used to test the validity of the research instrument while Cronbach alpha technique was used to calculate the reliability in which the Coefficient Index of 0.72 was obtained, thus instruments were considered reliable for data collection.

\section{Statistical Treatment of Data}

Data from questionnaires was analysed using descriptive statistics with the help of the Statistical Package for Social Sciences (SPSS version 20) software. Qualitative data was analysed thematically by arranging the data in categories and themes.

\section{Ethical considerations}

In carrying out the study, ethical principles were adhered to by seeking authorization from authorities. Participants were informed about the purpose and the importance of the study and anonymity and confidentiality were observed during and after data collection.

\section{Findings and Discussion}

Research Question: what are the strategies used in mobilization of physical resources among public secondary schools in Kilolo District?

\section{Fund Raising}

Table 1 (p. 85) shows that while $68.4 \%$ of respondents disagreed that their schools conduct fund raising for physical resources mobilization, $12.6 \%$ agreed with the statement. On the other hand, $19 \%$ were neutral. The findings show that the schools did not run fundraising programs for physical resources mobilization. Through interview with the heads of schools, it was equally commented that fund raising is not a common method for physical resource mobilization. Most of the heads of schools said that they often used funds received from the central government, which is capitation grant, to mobilize physical resources and 
educational facilities for effective curriculum implementation.

A study by Syacumpi (2012) in Zambia reports that in an attempt to address the funding gap, schools implemented different forms of fundraising ventures to mobilize resources either directly and indirectly. Schools prefer implementing direct fundraising approaches where they receive cash directly into their coffers, for example, through fees they ask learners to pay. On the other hand, indirect methods include donations and contributions from non-school participants and do not necessarily imply cash transactions. Therefore, it is important for public secondary schools under investigation to organize fund raising so as to collect fund which will be used in the mobilization of resources which are vital for effective curriculum implementation.

Table 1 Strategies used in the Mobilization of Physical Resources in Public Secondary Schools

\begin{tabular}{|c|c|c|c|c|c|c|c|}
\hline SN & Strategy & D & $\%$ & $\mathbf{N}$ & $\%$ & A & $\%$ \\
\hline 1 & $\begin{array}{l}\text { Our school conducts fund raising through organized program so } \\
\text { as to collect funds through the sale of tickets. }\end{array}$ & 54 & 68.4 & 15 & 19.0 & 10 & 12.6 \\
\hline 2 & $\begin{array}{l}\text { Our school uses money obtained from income generating } \\
\text { activities to mobilize physical resources. }\end{array}$ & 15 & 19 & 6 & 7.6 & 58 & 73.4 \\
\hline 3 & $\begin{array}{l}\text { Our school mobilizes physical resources through project write- } \\
\text { ups. }\end{array}$ & 37 & 46.8 & 18 & 22.9 & 24 & 30.3 \\
\hline 4 & $\begin{array}{l}\text { There is community involvement in the physical resource } \\
\text { mobilization activities such as construction of school buildings } \\
\text { and the purchase/ repair of broken-down desks and tables. }\end{array}$ & 14 & 17.7 & 8 & 10.1 & 57) & 72.1 \\
\hline
\end{tabular}

Key: $\mathbf{D}=$ disagree, $\mathbf{N}=$ Neutral, $\mathbf{A}=$ Agree, $\mathbf{F}=$ Frequency

\section{Income Generating Activities}

Table 1 also indicates that $73 \%$ agreed that public schools used funds from income generating activities to mobilize physical resources which are important in teaching and learning while 19\% disagreed. On the other hand, $7.6 \%$ were neutral. From these findings, it can be argued that income generation activities are used to raise money for physical resources mobilization. A study by Odundo and Rambo (2013) revealed that schools with income generating activities had more resources than those schools with no income generating activities. This infers that having income generating activities is crucial. This is due to the fact that the money obtained from income generating activities can be used by schools to mobilize the needed resources such as buying furniture like table and chairs for students and sometimes repairing the broken out physical resources.

\section{Project Proposals}

Table 1 furthermore shows that some respondents (46.8\%) disagreed that public secondary schools request for donations through project write-ups so as to acquire physical resources. Moreover, 30.3\% agreed with the statement and 22.9 were neutral. The findings show that the schools somewhat mobilized physical resource for curriculum implementation through writing Project Proposal. Castillo (2014) indicates that the government and schools in particular, should realize that they need to desist from relying upon a single source of income and they should learn how to create good relationship with donors who can feel the challenges that schools face and provide them with the required support. Since schools are social organizations and need various forms of resources, they need to employ possible strategies of resource mobilization to acquire resources essential for effective teaching and learning.

\section{Community Involvement}

Table 1 indicates that $72.1 \%$ agreed that community is involved in the physical resource mobilization activities. These include making bricks as well as contribution of manpower in the construction of buildings like classrooms. On other hand, $17.7 \%$ disagreed and $10.1 \%$ were not sure. The interview reported that community is well involved in mobilization of physical resources. The findings show that public secondary schools under investigation engaged the community in the mobilization of physical resources. This is because society has a great responsibility to contribute in one way or another to the provision of quality education for students whose profession will contribute back significantly to the development of the nation in various ways. 
According to International Labor Organization (2012), there is a need to acquire resources through several sources including local communities, private sectors, decentralized government budget, national and international organizations as well as development partners. Furthermore, Siperato (2018) recommends that the government, in collaboration with local community, should build sufficient schools in Wards in order to minimize crowded classrooms especially in the overpopulated regions. Therefore, resource mobilization and improvement of school physical resources require a collective strategy whereby stakeholders like students, parents, teachers together with the government must be collectively involved.

\section{Conclusions and Recommendations Conclusions}

The study concludes that operating income generation activities was the most common strategy utilized in mobilization of resources. Additionally the study shows that community involvement was also used to raise resources by heads of schools. It was also determined that to some extent, fundraising was used though not very commonly to mobilize resourced by school heads. Regarding project proposals, the study concluded that the strategy was shunned by most heads of schools.

\section{Recommendations}

Since physical resources are one of most important tools for curriculum implementation in education sectors including secondary schools, the study recommends that the use of different strategies to mobilize physical resources should be considered by schools under investigation. There is a need for Schools to continue investing in income generation activities, using funds generated to support curriculum implementation. Communities should be encouraged to continue supporting schools through participating in projects. Government should recognise communities that excel in supporting schools by appreciating their efforts and using generated funds transparently. Parents should be educated on advantages of adopting fundraising as a strategy for mobilisation of resources. To increase uptake of project write ups, heads of schools should be equipped with grant writing skills so as to enable them develop fundable proposals.

\section{References}

Abdulkareem, A. Y. \& Fasasi, Y. A. (2014). Management of education facilities in
Nigerian secondary schools: The roles of administrators and inspectors. International Journal of Educational Management, 2(1), 11-15.

Batti, R. (2014). Challenges facing local NGOs in resource mobilization. Humanities and Social Sciences, 2(3), 57 - 64.

Castillo, I. (2014). Resource mobilization. A practical guide for research and community-based organizations. (2nd Ed.). Philippines: Venture for Fund Raising, Inc.

Cheryan, S. Ziegler, S. A., Plant, V. C., Meltozoff, A.N. (2014). Designing the classroom to maximize student achievement. Policy. Insights Forum the Behavioral and Brain Science, 1(1), 4-12.

Dahie, A. M., Mohamed, A. A., and Mohamed R. A. (2017). School environment and academic performance: Empirical study from secondary schools in Mogadishu-Somaria. International Journal of Advance Engineering and Research Development, 8(3), 92-96.

Eric, A. \& Roseline, E. C. (2019). Physical resources availability and the academic performance of students in the universal basic education scheme, rivers state. International Journal of Innovative Development and Policy Studies, 7(1), 13-23.

International Labour Organization (ILO) (2012). Sustainability and resource mobilization strategy. International Program on the Elimination of Child Labour (IPEC) KEN0950USA.

Kanau, A. A., \& Haruna, M. J. (2013). Towards promoting community participation in education in Nigeria. Academic Journal of Interdisciplinary Studies, 2(7), 131-136.

Lyimo, N. S., Too, J. K. \& Kipng'etich, K. J. (2017). Perception of teachers on the availability of instructional materials and physical facilities in secondary schools of Arusha district, Tanzania. International Journal of Educational Policy Research and Review, 4(5), 103-112. 
Makore, O. O. H. \& Shukuru, H. H. S. (2017). Academic achievement of students does not depends on the process of teaching but also effectiveness of staff management. DOI: https://doi.org/10.2991/coema-17.2017

Muhangi, G. T. (2019). Secondary education in Uganda: Resource mobilization and efficiency. Journal of Education and Practice, 19(20).

Mutindi, M. J. (2018). School-based factors influencing students' performance in Kenya certificate of secondary examination in public secondary schools in Kathiani subcounty (Research project). South Eastern Kenya University.

Nzikako, J. A., \& Warue, B. (2018). An assessment of strategies used on resources mobilization: A case of the Université Chrétienne Bilingue $\mathrm{Du}$ Congo (UCBC). The University Journal, (2), 97-112.
Odundo, P., \& Rambo, M. (2013). Effect of schoolbased income generating activities on the financial performance of public secondary schools in Kenya. Chinese Business Review, 12 (6), 375-394.

Oladeji, O. (2019). Effects of physical structure on the academic performance of pupils in some selected primary schools in Abeokuta North Local Government Area of Ogun State. (Unpublished B.Ed project), National Open University of Nigeria, Abuja.

Siperato, B. (2018). Secondary school teachers experience in managing large classes size, Dar es Salaam. The Open University of Tanzania Publisher.

Syacumpi, M. (2012). Resource mobilization and fundraising in basic schools: A case study of Copperbelt and North-Western province. Lusaka, Zambia: Zambia Institute for Policy Analysis and Research. 